Corrigendum

\title{
Corrigendum \#2 to "Effects of Chronic Exposure to Sodium Arsenite on Expressions of VEGF and VEGFR2 Proteins in the Epididymis of Rats"
}

\author{
Dai Yan-Ping $\mathbb{D}$, ${ }^{1,2}$ Gao Xiao-Qin $\mathbb{D}^{3},{ }^{3}$ Ma Xiao-Ping, ${ }^{3}$ and Yue Ying-Quan ${ }^{3}$ \\ ${ }^{1}$ Department of Histology and Embryology, Guizhou Medical University, Guiyang, Guizhou 550004, China \\ ${ }^{2}$ People's Hospital in Yueyanglou District, Yueyang, Hunan 414000, China \\ ${ }^{3}$ Department of Histology and Embryology, Zunyi Medical and Pharmaceutical College, Zunyi, Guizhou 563000, China \\ Correspondence should be addressed to Gao Xiao-Qin; gxq550301@sina.com
}

Received 16 August 2018; Accepted 27 August 2018; Published 28 November 2018

Copyright (C) 2018 Dai Yan-Ping et al. This is an open access article distributed under the Creative Commons Attribution License, which permits unrestricted use, distribution, and reproduction in any medium, provided the original work is properly cited.

In the article titled "Effects of Chronic Exposure to Sodium Arsenite on Expressions of VEGF and VEGFR2 Proteins in the Epididymis of Rats" [1], there was an error in the third affiliation. The corrected authors' list and affiliations are shown above.

\section{References}

[1] D. Yan-Ping, G. Xiao-Qin, M. X. Ping, and Y. Y. Quan, "Effects of chronic exposure to sodium arsenite on expressions of VEGF and VEGFR2 proteins in the epididymis of rats," BioMed Research International, vol. 2017, Article ID 2597256, 9 pages, 2017. 

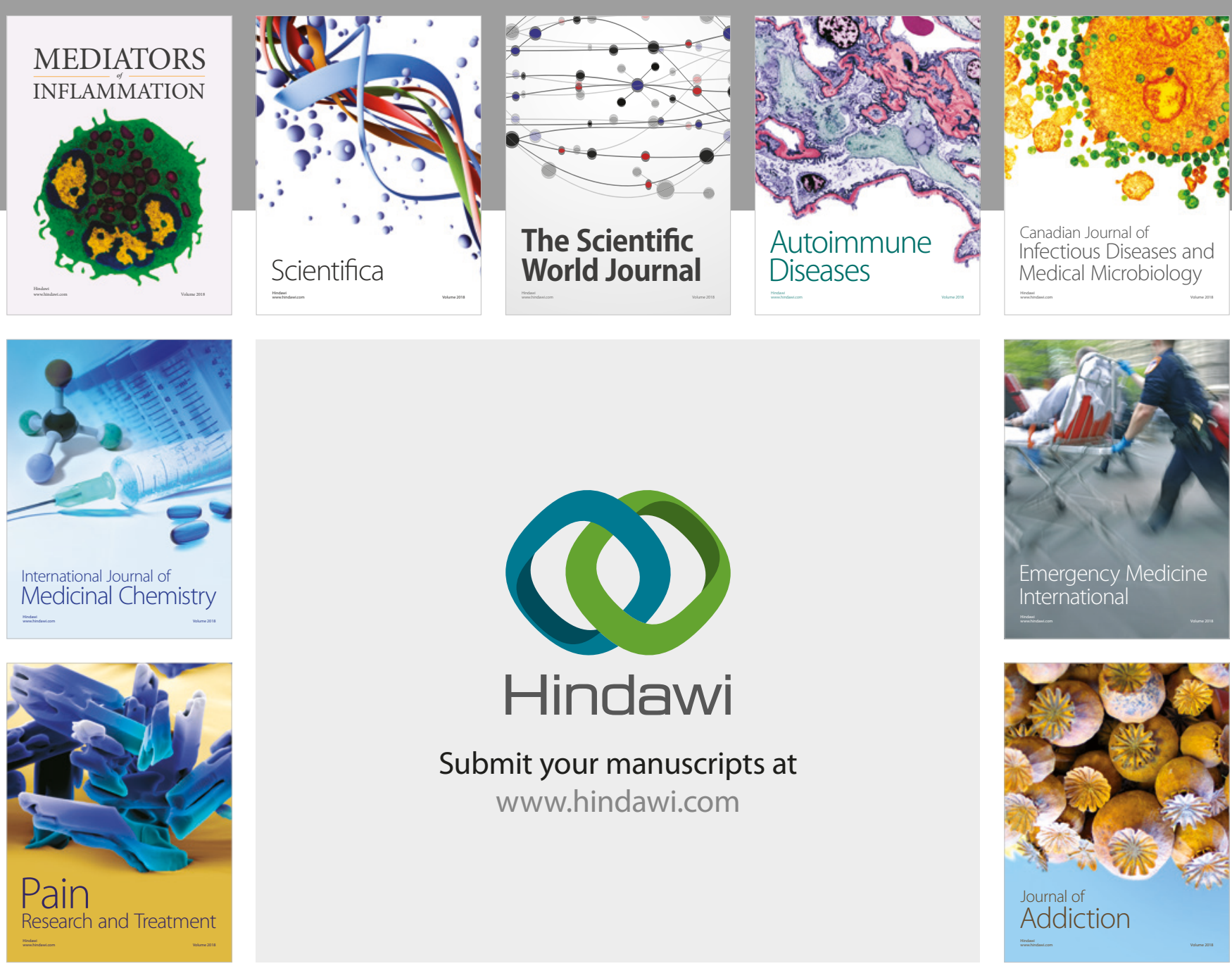

Canadian Journal of
Infectious Diseases and Medical Microbiology

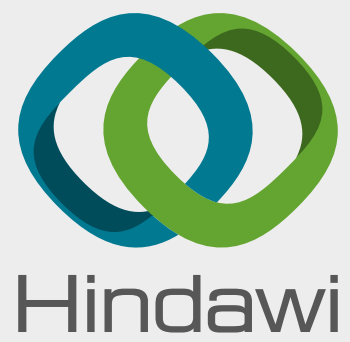

Submit your manuscripts at

www.hindawi.com
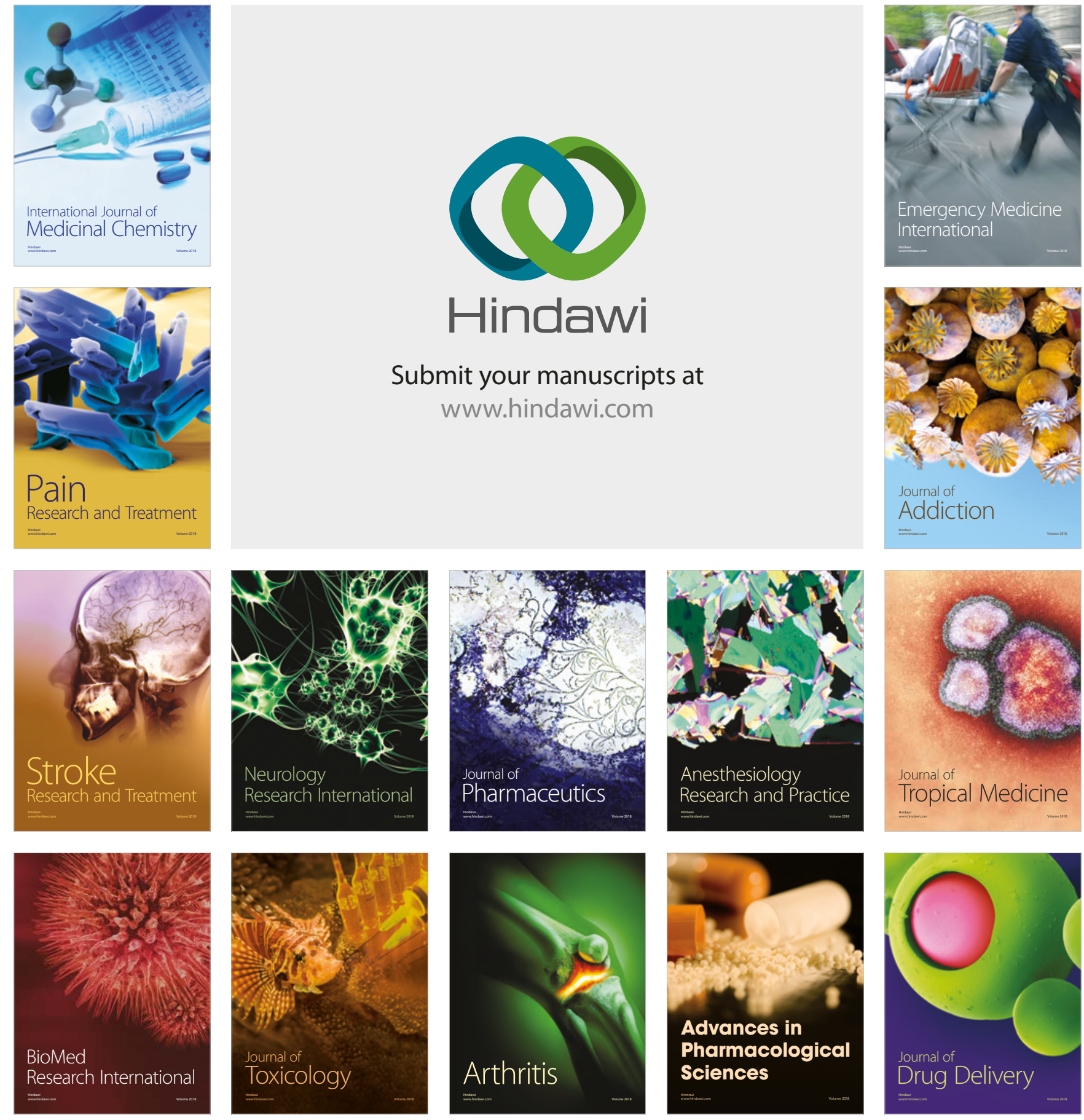